\title{
Method to reduce low temperature stress (LTS) in red raspberry (Rubus idaeus L.)
}

\author{
Rolf Nestby ${ }^{\mathrm{a}, *}$ and Fumiomi Takeda ${ }^{\mathrm{b}}$ \\ ${ }^{a}$ Norwegian Institute of Bioeconomy Research (NIBIO), Food and Agricultural Division (Horticulture), As, Norway \\ ${ }^{\mathrm{b}}$ U.S. Department of Agriculture, Agricultural Research Service, Appalachian Fruit Research Station, Kearneysville, \\ WV, USA
}

Submitted 4 May 2015; accepted 10 July 2015

\begin{abstract}
.
BACKGROUND: In Nordic regions the floricane of red raspberries often suffer $20-30 \%$ injury from exposures to low temperatures.

OBJECTIVE: Implemented methods to improve winter survival of red raspberry.

METHODS: We studied from 2011 to 2014 the bending and covering effect of red raspberry floricanes of 'Glen Ample', 'Stiora' and selection KV91-39-7 on winter injury and yield. Canes were trained to a rotating cross-arm (RCA) trellis system and covered with two layers of polyethylene (Agricover) sheets, and supplemental heat was provided at critical temperatures.

RESULTS: Bending plus heating reduced freezing injury of buds for all cultivars, and tended to increase yield for 'Stiora' and KV91-39-7, but not for 'Glen Ample'. Plots lifted directly to vertical after winter covering yielded more than plots where canes were left horizontal till anthesis and then lifted to vertical.

CONCLUSIONS: The experiments show that bending raspberry canes to avoid freezing injury, was possible without much visible cane injury if bending was undertaken carefully using a RCA trellis. However, standard trellising with erect canes improved fruit yield. It was found that a few more cane buds were torn off because of trellising reducing the amount of buds compared to canes in erect position. Additional studies should be undertaken to look at reasons why better cane survival resulted in lower yields.

Keywords: Freezing injury, cultivars, fruit yield, fruit weight, laterals, cane buds
\end{abstract}

\section{Introduction}

The first hardening phase of woody plants is initiated by the exposure to temperatures slightly above zero making the protoplast ready for the next hardening phase which take place around $-5^{\circ} \mathrm{C}$. The highest level of hardening is achieved by uninterrupted exposure to at least -5 to $-15^{\circ} \mathrm{C}$, although the effective temperature range differs for each plant species. However, above $0^{\circ} \mathrm{C}$, particularly in late winter, cause a rapid loss of resistance [1]. Floricane raspberries grown in the open follow the pattern of woody plants. In spite of the ability to harden to sustained low temperatures the temperature conditions in the Nordic states and even in continental Europe, often drop below the tolerance level of raspberries. The tolerance level differ during the winter season with the highest tolerance in January when canes and buds may survive temperatures below $-30^{\circ} \mathrm{C}$, while $-5^{\circ} \mathrm{C}$ in early May can kill the bursting buds. Depending on location the injury could be very serious making it a hazard to grow them. In midNorway (N63 $47^{\prime}$; E10 $92^{\prime}$ ) the summer season is optimal for growing raspberries, but winter and early spring temperatures limit the commercial growth to districts at low altitude near sea level, where only a limited number of cultivars are grown successfully $[2,3]$. Freezing injury normally occurs from November until freezing temper-

*Corresponding author: Rolf Nestby, Norwegian Institute of Bioeconomy Research (NIBIO), Food and Agricultural Division (Horticulture), 1431 Ås, Norway. Tel.: +47 9598 8530; Fax: +47 7482 2008; E-mail: rolf.nestby@ nibio.no. 
atures end in April/May. It appears as a tip dieback with more or less injured cane buds on the living part of the cane.

Although raspberries in a dormant stage can resist low temperatures down to $-30^{\circ} \mathrm{C}$ or colder, warm spells will lead to loss of freezing tolerance, and when it gets cold again freezing tolerance will not increase to the previous level, and for each mild spell there will be a new loss of freezing tolerance [3-6]. Injury could be reduced by choosing a suitable cultivar and site, or protection method to prevent injuries from exposure to low winter temperatures. In areas where summer and autumn temperatures are not sufficient for raspberries to grow properly and yield adequately, walk-in polyethylene-covered tunnels are used. Erect and semi-erect blackberries can now be grown in areas where winter temperatures drop below $-25^{\circ} \mathrm{C}$. This was achieved by the use of a rotating cross-arm (RCA) trellis system [7-10] which is similar to the Stiles shift trellis [11]. This system can also be used in raspberries. It makes it possible to train the primocanes to grow upright by tying them to wires on the trellis, and in late autumn rotate the arm down so that the canes are bent close to the ground allowing them to be protected from freezing temperatures with a suitable covering material, and in our northern conditions obtain additional protection with natural snow on top of the cover.

The experiments were conducted to determine if the RCA trellis would be suitable for growing raspberry and reducing winter injury at locations with harsh winter climate in combination with winter cowering and adding of heat below the cover.

\section{Material and methods}

\subsection{The experimental field}

The study was undertaken in an $7 \mathrm{~m}$ wide and $50 \mathrm{~m}$ long open polytunnel on farm land in mid-Norway $\left(63^{\circ} 46^{\prime} \mathrm{N}\right.$, $11^{\circ} 16^{\prime} \mathrm{E}$ ), with two raised beds $20 \mathrm{~cm}$ high and $90 \mathrm{~cm}$ wide spaced $3 \mathrm{~m}$ apart (Fig. 1). On each bed, two drip lines (Netafim Dripnet) were placed $15 \mathrm{~cm}$ apart. The drip line has a pressure-compensated drip nozzle placed at $50-\mathrm{cm}$ intervals with discharge rate of $1.6 \mathrm{~h} \mathrm{~h}^{-1}$ [Dryppvanning AS, Norway (Israel)]. The beds were mulched with woven black polyethylene plastic mulch (LOG 'jorddekkeduk', Norway). In July 2009, greenhouse-matured raspberry plants (30-cm tall) were established in circular openings $(20-\mathrm{cm}$ diameter) in the plastic mulch spaced $50-\mathrm{cm}$ apart. The polytunnel was covered with roof sheeting from early May to early October each year of the experimental period which was from 2011 to 2014. Fertigation (irrigation and fertilization combined) were undertaken once a week in

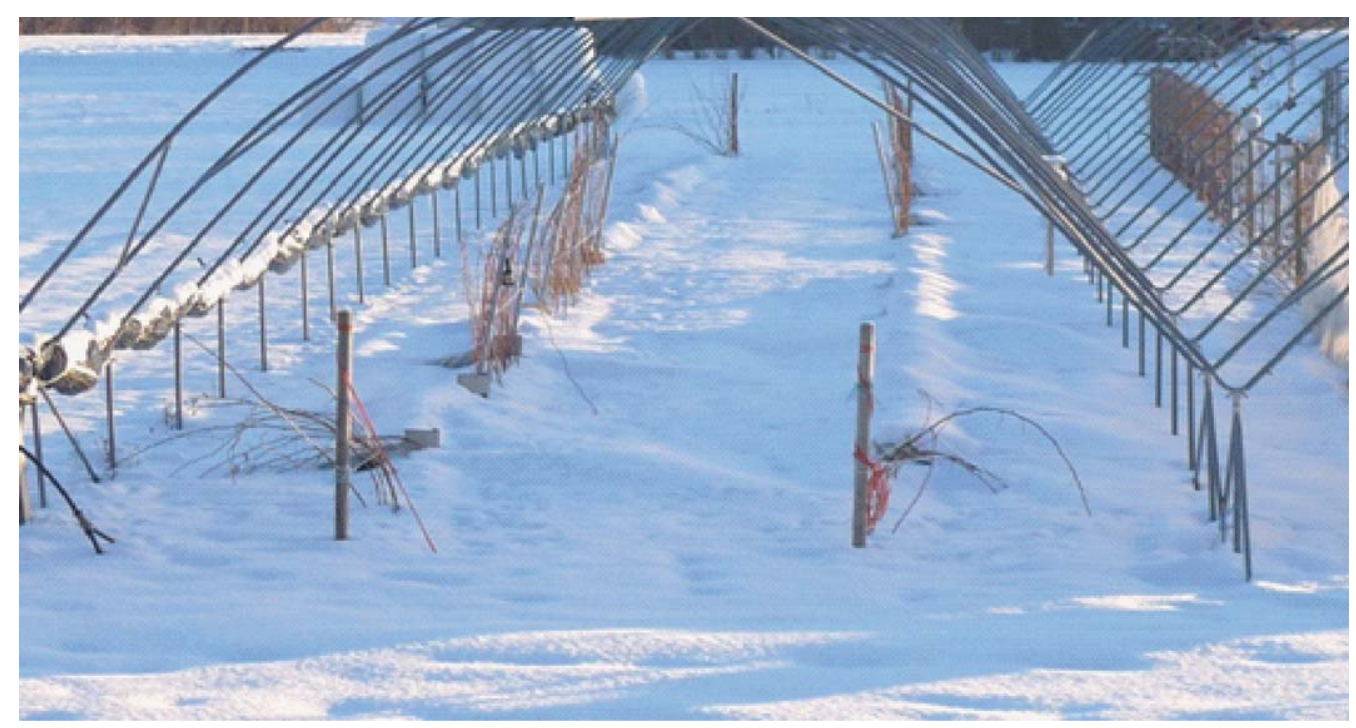

Fig. 1. The experimental field in winter with canes in bent plots covered with snow and canes in control plots in upright orientation. 
accordance with the plant development. Additional water was applied at a tension treshhold of $20 \mathrm{Cb}$. Weeding and control of diseases and pesticides were according to regional standard procedures for growing in polytunnel.

\subsection{The experimental design}

The experiments are undertaken in a split plot design with two replications and two large plots in each block. One of the large plots was heated at threshold temperatures, while the other was not. The large plot contained six small plots each with seven plants. In the heated large plot two of the small plots were idle (reserve plots), that were treated similar to the other four small plots of the large plot all years, except the last year when four of the idle plots were added to the experimental design as treatment $\mathrm{E}(\mathrm{CBH}$, Table 1$)$.

All recordings in a small plot were undertaken on the three central plants. Each plant was pruned leaving four canes in early spring. Treatment A = Genotype ('Glen Ample', 'Stiora', KV 91-39-7); Treatment B = B (Bent, bending and winter covering of canes); Treatment $\mathrm{C}=\mathrm{BH}\left(\mathrm{Bent} \_\mathrm{H}\right)$, similar to B except that heat was added under the winter cover; Treatment $\mathrm{D}=$ Erect canes $(\mathrm{C}$ or Control); Treatment $\mathrm{E}=\mathrm{CBH}(\mathrm{Control} \mathrm{BH})$ in 2014; canes on idle plots, similar to treatment $\mathrm{B}$ except that the canes were trained directly vertical just before bud burst.

For Winter cover was used a double layer of Agrocover (Rovero, the Netherlands), which was removed each year in April/May when the chance of freeze injury on cane buds was absent. Heating was provided by one tube-formed oven (HYTH 454/56, 180 W; Hylite Manufacturing LTD, Heywood UK) per small plot. The ovens were connected to a thermostat inducing heating at ambient air critical minimum temperatures, which was decided to be $-15^{\circ} \mathrm{C},-10^{\circ} \mathrm{C}$ and $-5^{\circ} \mathrm{C}$ (by experience) respectively in the periods 1 November to 28 February, in March and in April. A lamp connected to the thermostat visualized heating. The temperature was recorded under the winter cover. In April/May bent canes in treatments $\mathrm{B}$ and $\mathrm{C}$ were lifted to horizontal position allowing laterals to grow upwards. At anthesis (first flower) they were lifted into an upright position.

\subsection{The trellis}

A special trellis was used to bend floricanes. The trellis used was a copy of the rotating cross arm trellis (RCA) system, available from Trellis Growing Systems (Fort Wayne, IN USA). The post was a square iron $\operatorname{rod}\left(4 \times 4 \mathrm{~cm}^{2}\right)$ driven $50 \mathrm{~cm}$ into the soil leaving $40 \mathrm{~cm}$ above soil (Fig. 2). At the top of the post, two iron metal plates were bolted with wing nuts. In between the two plates two cross-arms were inserted and their bases secured with a pin. Additional holes were drilled through the plates. Another pin was inserted through the plates and the cross-arm. The wires

Table 1

Description of experimental treatments of one block in the raspberry field trial, number of replicates and total number of small plots (R/SP) in mid-Norway in the years 2010-2014

\begin{tabular}{|c|c|c|c|c|}
\hline Treatment & Description & Time period & Abbreviation & $\mathrm{R} / \mathrm{SP}$ \\
\hline \multirow[t]{3}{*}{ A. Genotype } & Glen Ample & Continuous & & $2 / 8$ \\
\hline & Stiora & & & $2 / 8$ \\
\hline & KV 91-39-7 & & & $2 / 6$ \\
\hline B. Bending of canes & Horizontal till anthesis and covered & $\begin{array}{l}\text { Oct-June Horizontal } \\
\text { Oct-April Cover }\end{array}$ & B (Bent) & $2 / 6$ \\
\hline C. Bending of canes & $\begin{array}{l}\text { As } \mathrm{B} \text {, but adding heat at threshold } \\
\text { temperatures. }\end{array}$ & $\begin{array}{l}\text { Oct-June Horizontal } \\
\text { Oct-April Cover } \\
\text { Oct-April Heat }\end{array}$ & BH (Bent-H) & $2 / 6$ \\
\hline D. Erect canes & $\begin{array}{l}\text { The canes were always in erect } \\
\text { position. }\end{array}$ & & $\mathrm{C}$ (Control) & $2 / 6$ \\
\hline $\begin{array}{l}\text { E. Erect canes after the } \\
\text { covering period. }\end{array}$ & $\begin{array}{l}\text { Similar to treatment } C \text {, but canes } \\
\text { were lifted to erect position before } \\
\text { bud burst. }\end{array}$ & $\begin{array}{l}\text { Oct-April Horizontal } \\
\text { May-Sept Erect } \\
\text { Only last season }\end{array}$ & CBH (Control_BH) & $2 / 4$ \\
\hline
\end{tabular}




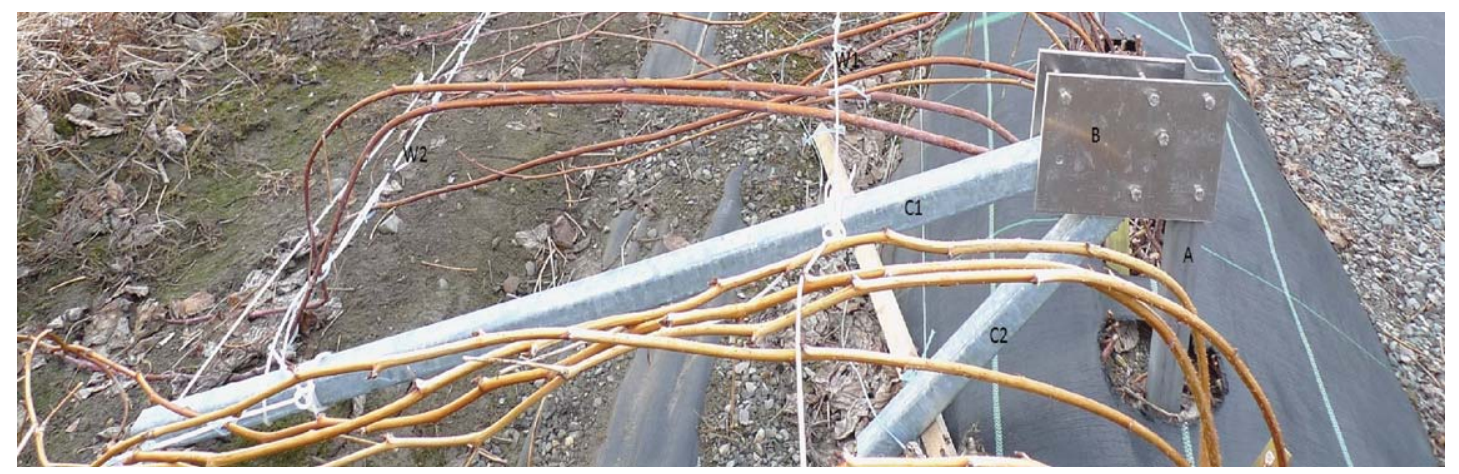

Fig. 2. The RCA trellis consists of a metal post (A) with two plates (B) at the top of the post. Between the two plates, two cross arms (C1 long; $\mathrm{C} 2$ short) are secured by inserting a pin through their base. With the canes secured to two wires (W1 and W2) on the rotatable cross-arms, cane orientation can be changed from vertical during the growing season to horizontal or even closer to the ground in winter.

on long and short cross arms supported floricanes and primocanes, respectively, allowing them to move in wanted positions (bent to the ground, horizontal and upright). To support the canes a cane training system with two wires on the rotating cross arms was used to allow a hedge height of $160 \mathrm{~cm}$ (Fig. 2). The plants were topped at first bud above $160 \mathrm{~cm}$ height in early spring spaced $\sim 12.5 \mathrm{~cm}$ apart on the top wire.

\subsection{Data collection}

Fruits were harvest twice a week from the end of July to the middle of September each year. Total fruit yield was recorded in grams and weighed fruit size was calculated based on fruit size and fruit yield at each harvest. Percentages salable, rotted and crumbly fruit were calculated, but not tabulated since levels of salable was almost equivalent to total yield because of few rotted and crumbly fruits. In spring 2012, 2013 and 2014 freezing injury was registered by evaluating the development of vegetative buds on the upper two thirds of the cane two weeks after bud burst, using a $0-9$ scale where 0 is $100 \%$ dead buds/laterals and 9 is $100 \%$ fresh buds/laterals. The percentage injury (dead buds) represented by scores between 9 and 0 was: score $8=0.1-13.1 \%, 7=13.2-26.2 \%, 6=26.3-36.3 \%, 5=36.4-47.4 \%$, $4=47.5-60.5 \%, 3=60.6-73.6 \%, 2=73.7-86.7 \%, 1=86.8-99.9 \%$. This is a simplification of a score table given earlier [12].

Because of experiences the first years, more detailed data collection was undertaken in 2014. Bud survival was recorded at the lower third, the mid third and the top third section of the cane. In addition number of buds destroyed by training the canes, total number of canes in the plot and number of canes lower than $160 \mathrm{~cm}$, were counted in spring after the final lifting of the trellis.

Climatic data was from a nearby (300 m distance) meteorological station, available on the web (eklima, Meterological Institute, Norway).

\subsection{Statistics}

Statistics, tables and graphs were undertaken using the SAS procedures GLM (Multivariate Anova with $P$-levels), tabulate and graph [13].

\section{Results}

\subsection{Ambient temperatures in three winter seasons and the effect of cover on temperature}

The effects of freezing injury of buds and subsequently on fruit yield parameters, are to a great extent influenced by the temperature patterns of the three test winters, in interaction with the treatments implemented to avoid freezing 

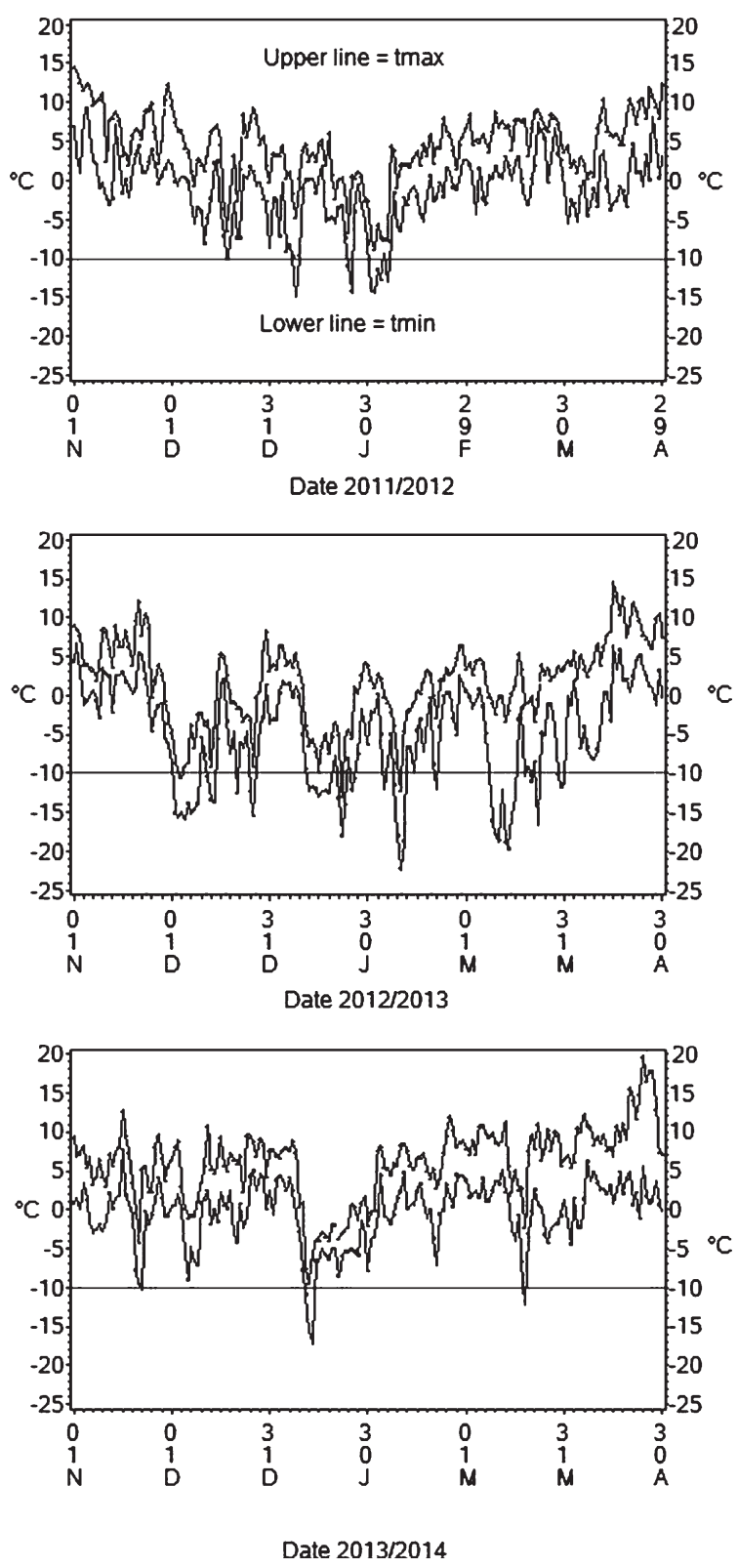

Fig. 3. Maximum and minimum temperatures $\left({ }^{\circ} \mathrm{C}\right)$ from beginning of November to end of April in three winter/spring seasons. The upper line represent maximum- and the lower line represent minimum-temperatures. The horizontal line at $-10^{\circ} \mathrm{C}$ indicate the critical temperature for development of freezing injury in March. The heath was turned on at ambient temperatures below this in March (similarly at $-15^{\circ} \mathrm{C}$ in January and $-5^{\circ} \mathrm{C}$ in April).

injury. The winter of 2011/2012 was relatively mild with temperatures that would not give freezing injury on normally developed cane buds. The temperature was not below the critical temperatures of $-15^{\circ} \mathrm{C}$ and $-10^{\circ} \mathrm{C}$, respectively in the periods 1 November to 28 February and in March. However, at a few occasions the temperature went below the critical temperature of $-5^{\circ} \mathrm{C}$ in April (Fig. 3). The snow cover was stable from 20 December to 20 March, but not thicker than $20 \mathrm{~cm}$ at any date. The temperature under BH (treatment C, Table 1) was not recorded that year, because of failure of the logger. The winter 2012/2013 was much colder and temperatures with bud freezing potential occurred 


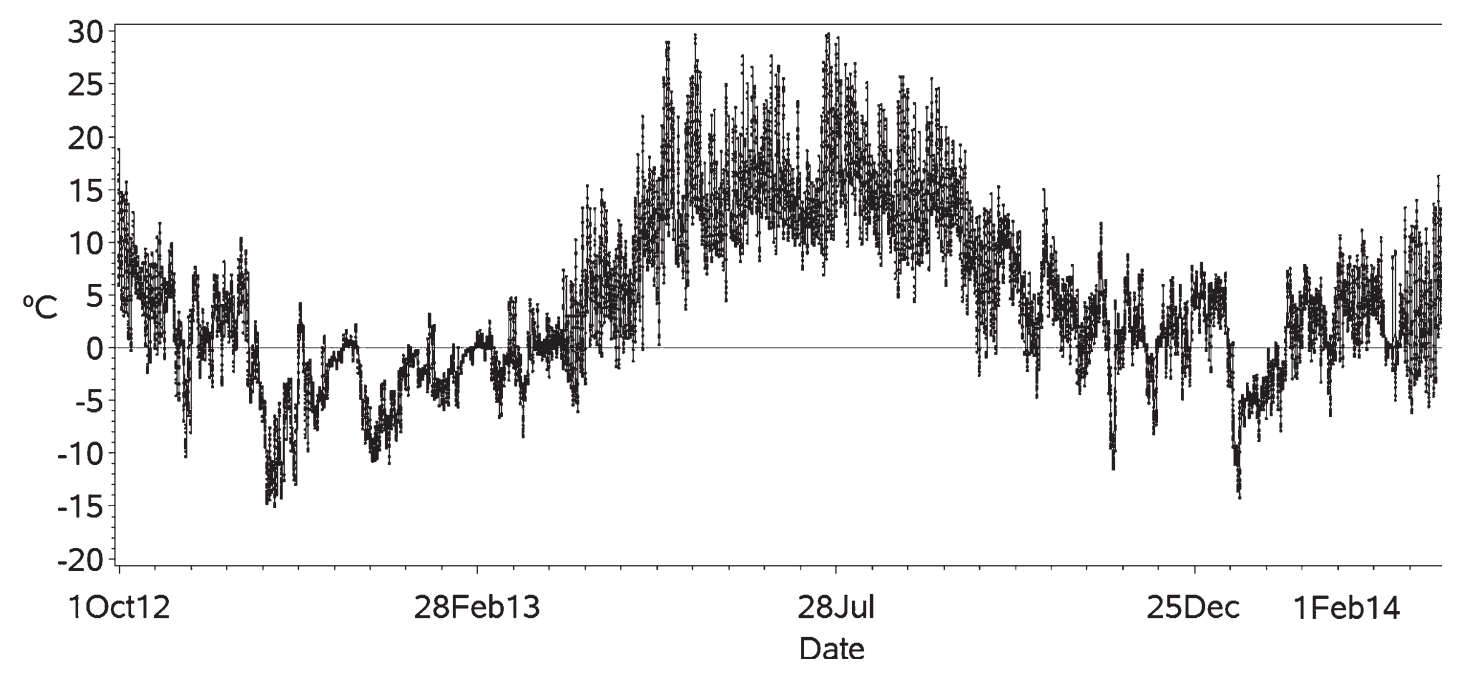

Fig. 4. Temperature in ${ }^{\circ} \mathrm{C}$ under the bent and covered treatment from October 2012 to May 2014.

in all months from December to 10 April. The snow cover was more unstable than the previous year, and in periods it blew off the top of the covering or rainfall melted the snow. However, the temperature under $\mathrm{BH}$ went down to $-15^{\circ} \mathrm{C}$ in January 2013 while the ambient temperature went down to $-16.2^{\circ} \mathrm{C}$ (Fig. 3; Fig. 4). The highest temperature in January was $+5.0^{\circ} \mathrm{C}$, while the temperature under cover and potential heat $(\mathrm{BH})$ varied from +2.3 to $-11.0^{\circ} \mathrm{C}$. Since the heating was active at several occasions in 2013 this is one reason of higher minimum temperature. A thin snow cover could have strengthened the effect. In the period February and March 2013 the ambient temperatures varied between +6.6 to $-22.8^{\circ} \mathrm{C}$. Under $\mathrm{BH}$ in the same period the temperature varied from +3.2 to -11.0 . The reduced maximum and increased minimum temperatures can be suggested a result of the covering itself, and of snow covering the BH treatment in periods combined with a heating effect in the cold spells of February and March. In April 2013 ambient temperature dropped to $-8.8^{\circ} \mathrm{C}$ and to $-8.2^{\circ} \mathrm{C}$ under $\mathrm{BH}$. It is important to note that the cover prevented the high ambient temperatures going up to $14.5^{\circ} \mathrm{C}$, which is important considering hardening and dehardening. The winter 2013/2014 was exceptional. It was mild, dry and windy and with no snow cover apart from a short period in early December. These conditions introduced a strong drought stress, which was the main stress factor. However, the temperature went below the critical temperature $\left(-15^{\circ} \mathrm{C}\right)$ for a couple of days in mid-January 2014 and below the critical temperature $\left(-10^{\circ} \mathrm{C}\right)$ for one day in mid-March. The drop in ambient temperature in mid-January 2014 to $-17.5^{\circ} \mathrm{C}$ was answered by a drop to $-14.2^{\circ} \mathrm{C}$ under $\mathrm{BH}$ and $\mathrm{CBH}$, showing an improvement by the treatment (Fig. 3, Fig. 4). Similarly in mid-March BH and $\mathrm{CBH}$ improved the temperature with $6.1^{\circ} \mathrm{C}$ compared to ambient that dropped to $-12.5^{\circ} \mathrm{C}$; a combined effect of covering and heating.

It is shown that the large differences in climate between the years had potential to induce differences in injury of the cane buds by freezing or drought stress. It is also shown that covering and heating strongly influenced temperature. These factors would have a potential influence on fruit yield and yield parameters.

\subsection{Effects on cane and cane buds by treatment}

Observations in spring any year did not show visible cracking of canes in the bent area. In 2014 more detailed examinations were introduced. These examinations showed that only two canes (of more than 1000) were torn off the mother plant during the bending and lifting procedures in the previous autumn and winter (not tabulated). Because of this it was enough canes evaluated as unharmed to achieve full plots for the growing season.

Freezing injury of cane buds was reduced by bending and covering of canes. However, the winter of $2011 / 2012$ was mild with the lowest temperatures approximately at $-13^{\circ} \mathrm{C}$ on three occasions in January and February, and it was close to critical temperature $\left(-5^{\circ} \mathrm{C}\right)$ in April (Fig. 3). The heating was therefore activated only a few times in early April, and all treatments gave a freezing injury score higher than 7.5 , but 


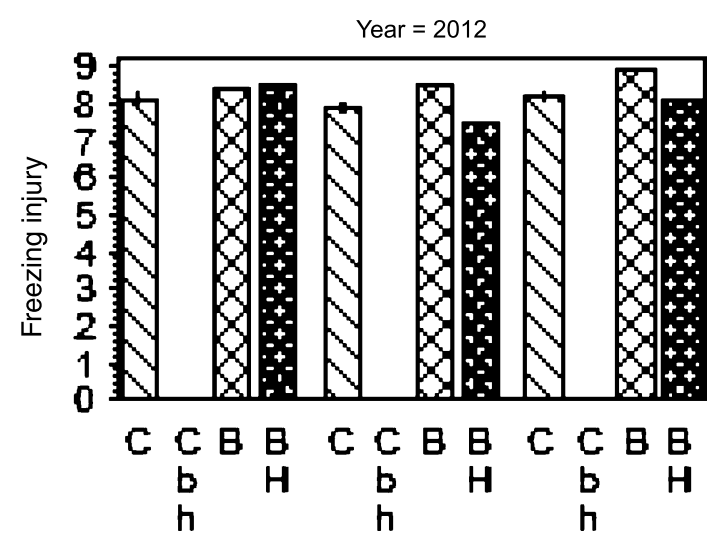

Glen Ample Stiora Kv91-39-7

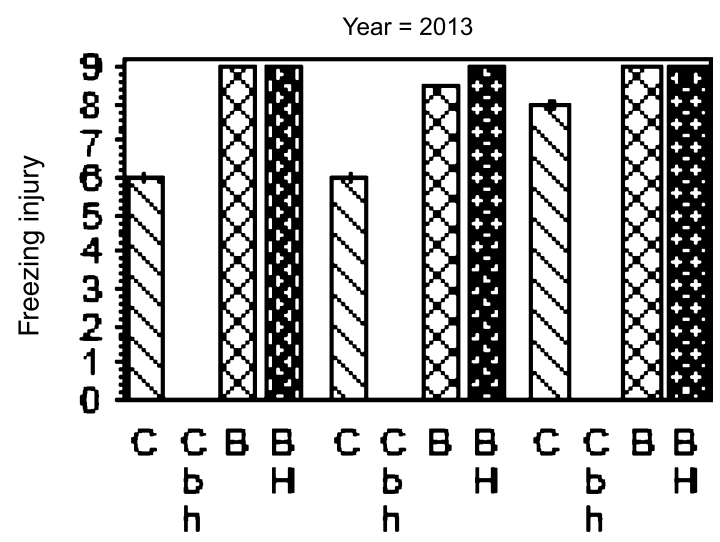

Glen Ample Stiora Kri-39-7

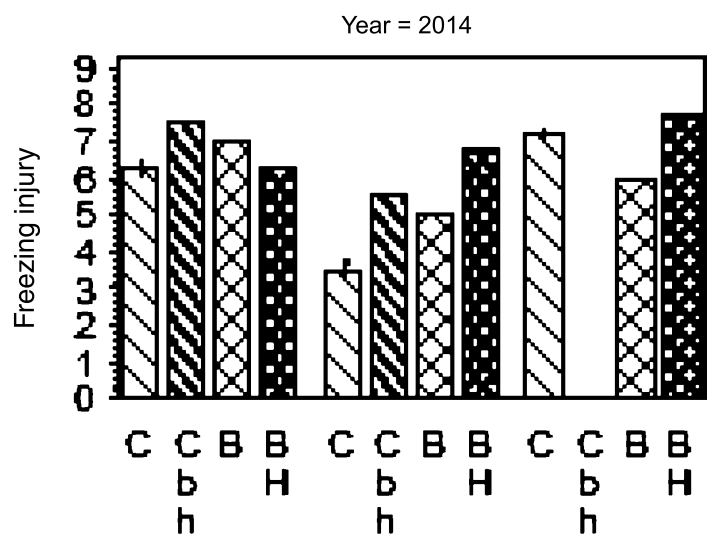

Glen Ample Stiora KV91-39-7

Fig. 5. The effect of low-temperature stress avoidance treatments on freezing injury (rated $0-9$ where 0 is dead buds and 9 fresh buds), in cane buds of three raspberry cultivars in three years in mid-Norway. $\mathrm{C}=$ erect canes the whole year $(\mathrm{Control}=$ treatment $\mathrm{D}) ; \mathrm{Cbh}=$ erect canes April-October 2014 at bent and heated plots; B = bent and covered plots with erect canes May-October; BH = bent and heated plots October-May. Cbh is similar to BH except that canes were raised into erect position approx. one month earlier than for BH. Bars on the top of the left column of each cultivar indicate standard error within the cultivar. 
the differences between treatments were not significant (Fig. 5). The next winter was cold, and heating was activated at several occasions throughout the whole winter into early April (Fig. 3). Under these conditions erect canes (C) had more freezing injury of buds than bent and covered canes. Bending and covering reduced the freezing injury of buds to almost none, and no additional improvement caused by heating was observed (Fig. 5).

The winter 2013/2014 was not cold, and the temperature reached critical level on only one day in mid-January and also in mid-March (Fig. 3). However, there was no snow cower (and no rain for two months) and steady hard and dry winds were prevalent into March. Extensive drought damage was observed in the heather plants growing

Table 2

Average effect of freezing injury of cane buds in distal- and middle- third of the cane, for three raspberry genotypes and four bending treatments, registered in May 2014 in mid-Norway

\begin{tabular}{|c|c|c|c|}
\hline \multirow[t]{2}{*}{ Genotype } & \multirow[t]{2}{*}{ Treatment } & \multicolumn{2}{|c|}{ Freezing injury } \\
\hline & & Distal & Middle \\
\hline \multirow[t]{4}{*}{ Glen Ample } & Control & 5.5 & 7.0 \\
\hline & Control_BH ${ }^{1}$ & 7.5 & 7.5 \\
\hline & Bent & 7.0 & 7.0 \\
\hline & Bent_H & 7.0 & 5.5 \\
\hline S.error & & $0.4^{\mathrm{ns}}$ & $0.3^{\mathrm{ns}}$ \\
\hline \multirow[t]{4}{*}{ Stiora } & Control & 3.5 & 3.5 \\
\hline & Control_BH ${ }^{1}$ & 5.5 & 5.5 \\
\hline & Bent & 4.5 & 5.5 \\
\hline & Bent_H & 6.5 & 7.0 \\
\hline S. error & & $0.3^{\mathrm{ns}}$ & $0.2^{\mathrm{ns}(P=0.17)}$ \\
\hline \multirow[t]{3}{*}{ KV91-39-7 } & Control & 6.5 & 8.0 \\
\hline & Bent & 5.0 & 7.0 \\
\hline & Bent_H & 7.5 & 8.0 \\
\hline S. error & & $0.1^{*}$ & $0.2^{\mathrm{ns}(P=0.18)}$ \\
\hline Mean & & 6.0 & 6.7 \\
\hline S. error ${ }_{\mathrm{cv}}$ & & $0.4^{*}$ & $0.5^{*}$ \\
\hline
\end{tabular}

$\mathrm{Ns}, *$ are not significant and significant on $5 \%$ level, respectively.

Table 3

Average effect for three raspberry genotypes of cane length, number of canes lower than $160 \mathrm{~cm}$ before topping and number of cane buds that was torn off caused by freezing avoidance treatment, as average of bending treatments recorded in May 2014 in mid-Norway. Full cane number per plot = 16

\begin{tabular}{lccc}
\hline Genotypes & \multicolumn{2}{c}{ Cane } & Bud \\
\cline { 2 - 4 } & Length cm & No $<160 \mathrm{~cm}$ & Torn off \\
\hline Glen Ample & 158 & 1 & 7.6 \\
Stiora & 149 & 5.9 & 5.6 \\
KV91-39-7 & 154 & 4.6 & 3.3 \\
\hline Mean & 154 & 3.8 & 5.5 \\
S. error & $1.3^{* *}$ & $0.4^{*}$ & $1.0^{\mathrm{ns}(P=0.076)}$ \\
\hline
\end{tabular}

$\mathrm{Ns}, *, * *$ are not significant, significant on $5 \%$ and $1 \%$ level, respectively. 
in surrounding areas. That year the bud injury on erect canes, especially in 'Stiora' (Fig. 5, Table 2), was attributed as a desiccation damage, rather than a freezing injury since injured buds were located along the entire two third top-length of the upright canes and not from the top and downwards as after freezing injury. It should be mentioned that 'Stiora' did not grow well in the clay loam soil of the experimental field, resulting in thin and short canes that often were less than $160-\mathrm{cm}$ tall and therefore did not require pruning or only a short length of the tip was pruned (Table 4). Also, KV91-39-7 reacted similarly to the clay loam soil as 'Stiora' growing short canes. However, the canes were more sturdy and thicker than for 'Stiora'. KV91-39-7 showed strong tolerance to the special climatic conditions with strong drought stress, and it adapted well to the bending treatments as did 'Stiora'. The relatively high injury score for 'Stiora' compared with 'Glen Ample', could be explained by weaker and shorter canes (Fig. 5, Table 3). Selection KV91-39-7 had less bud injury than 'Stiora'. On the lower third section the buds were resting for all cultivars. Number of buds that were torn off the cane by handling the trellis was reduced in this order 'Glen Ample' > 'Stiora' > KV91-39-7 (Fig. 6, Table 4), and CBH and BH had less injury than B.

\subsection{Effect on fruit yield parameters by treatments}

There was no interaction between year and freezing avoidance treatment for total yield and fruit size. Therefore annual results for these parameters are not tabulated. It was shown that standard training keeping the canes in an upright position the year round (Control) had higher fruit yield as a mean of genotypes and four years than for the two bending treatments (Table. 4). There were no differences in fruit weight between treatments, however because of the low yields of the bending treatments, compared to control, it would have been expected that the fruit weight should increase. The reduced fruit weight indicate a reduction in fruit number by bending. There was a tendency that the treatment with heating under the cover improved the winter survival as an average of all genotypes (Table 2). However, for 'Glen Ample' the added heat $(\mathrm{BH})$ tended to reduce yield, probably because of the increased winter injury compared with no heat (B), in contradiction to 'Stiora' and KV91-39-7 where added heat improved yield. Anyway, standard trellising with erect canes (Control) had highest yield, though it was not significantly higher than the heat treatment for 'Stiora' and the selection KV91-39-7. The amount of salable fruit was from 91 to 98 percentage of total yield, and the rest was rotted and crumbly fruits. The effects by treatments on the percentage of these yield parameters were minor and generally not significant (not tabulated).

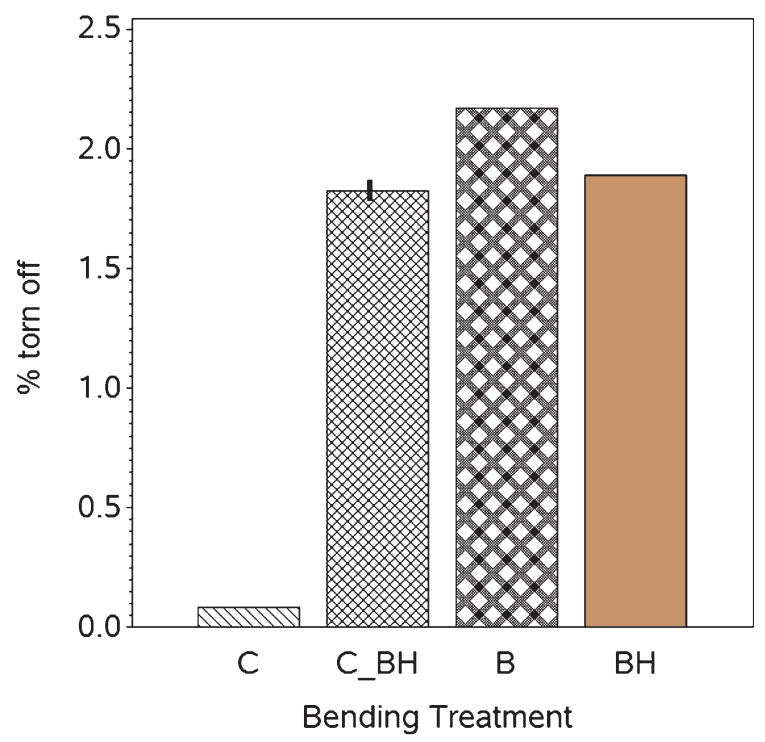

Fig. 6. Effect of freezing avoidance treatment on percentage of cane buds that was torn off after trellis handling of primocanes in late autumn 2013 in mid-Norway as average of three genotypes. Bar on top of the left column indicate standard error $(P=0.0026)$. 
Table 4

Average total fruit yield in $\mathrm{kg} \mathrm{m}^{-2}$ and fruit weight (fw) in gram fruit ${ }^{-1}$ of four years (2011-2014) for three floricane raspberry genotypes, as a result of methods to reduce freezing injury in a polytunnel field trial in mid-Norway

\begin{tabular}{|c|c|c|c|c|c|c|c|c|}
\hline \multirow[t]{3}{*}{ Treatment } & \multicolumn{8}{|c|}{ Cultivar } \\
\hline & \multicolumn{2}{|c|}{1 'Glen Ample' } & \multicolumn{2}{|c|}{2 'Stiora' } & \multicolumn{2}{|c|}{3 KV91-39-7 } & \multicolumn{2}{|c|}{ Mean } \\
\hline & Yield & fw & Yield & fw & Yield & fw & Yield & Fw \\
\hline Control & 2.3043 & 5.79 & 1.4908 & 5.66 & 1.3272 & 4.01 & 1.7074 & 5.15 \\
\hline B & 1.7085 & 5.70 & 1.1273 & 5.74 & 0.9928 & 3.49 & 1.2762 & 4.98 \\
\hline $\mathrm{BH}$ & 1.6382 & 5.68 & 1.3745 & 5.85 & 1.1564 & 3.92 & 1.3897 & 5.15 \\
\hline Mean & 1.8807 & 5.72 & 1.3308 & 5.75 & 1.1588 & 3.81 & 1.4568 & 5.09 \\
\hline S. error & $0.1744^{*}$ & $0.34^{\mathrm{ns}}$ & $0.0853^{* *}$ & $0.44^{\mathrm{ns}}$ & $0.1355^{\mathrm{ns}}$ & $0.23^{\mathrm{ns}}$ & $0.0775^{* * *}$ & $0.20^{\mathrm{ns}}$ \\
\hline
\end{tabular}

$\mathrm{Ns}, *, * *, * * *$ are not significant, significant on $5 \%, 1 \%$ and $0,1 \%$ level, respectively.

Table 5

Total fruit yield in $\mathrm{kg} \mathrm{m}^{-2}$ and fruit weight (fw) in gram fruit ${ }^{-1}$ for two floricane raspberry cultivars, as a result of methods to reduce freezing injury in a field polytunnel trial in mid-Norway, in 2014. ( $P=0.099$ for mean)

\begin{tabular}{|c|c|c|c|c|c|c|}
\hline \multirow[t]{3}{*}{ Treatment } & \multicolumn{6}{|c|}{ Cultivar } \\
\hline & \multicolumn{2}{|c|}{1 Glen Ample } & \multicolumn{2}{|c|}{2 Stiora } & \multicolumn{2}{|c|}{ Mean } \\
\hline & Yield & fw & Yield & fw & Yield & fw \\
\hline Control & 2.7069 & 5.02 & 1.5370 & 5.15 & 2.1220 & 5.09 \\
\hline $\mathrm{CBH}^{1}$ & 2.3024 & 4.97 & 1.4311 & 5.21 & 1.8668 & 5.09 \\
\hline B & 2.1043 & 5.00 & 1.4213 & 4.76 & 1.7628 & 4.34 \\
\hline $\mathrm{BH}$ & 2.0841 & 5.00 & 1.3580 & 4.70 & 1.7211 & 4.39 \\
\hline Mean & 2.2994 & 5.00 & 1.4367 & 4.96 & 1.8682 & 4.98 \\
\hline S. error & $0.0684^{\mathrm{ns}}$ & $0.14^{\mathrm{ns}}$ & $0.1112^{\mathrm{ns}}$ & $0.19^{\text {ns }}$ & $0.0789^{\mathrm{ns}}$ & $0.09^{\mathrm{ns}}$ \\
\hline
\end{tabular}

Ns are not significant. ${ }^{1}$ Plants of 'Glen Ample' and 'Stiora' from bent and heated plots trained in erect position, in early spring 2014.

In 2014 idle plots (CBH) were introduced to examine if the result of bending till anthesis (B and $\mathrm{BH}$ ) gave a general reduction in yield compared with $\mathrm{CBH}$. This could be caused by the technique of forcing laterals in one direction at anthesis. For the two cultivars tested the standard erect canes (Control) still produced the highest yield, but the bent canes, given the opportunity to grow laterals naturally $(\mathrm{CBH})$, tended to give higher yield than treatment B and C (respectively B and BH) for 'Glen Ample' (Table 5), the benefit was smaller and not significant for 'Stiora' $(p=0,099)$. There were no significant differences in fruit weight, but 'Stiora' had a strong tendency to develop larger fruit weight in control and CBH compared with B and BH. It could be suggested that forcing the laterals to one side partly could explain the reduced yield compared to standard trellis.

\section{Discussion}

These experiments showed that the method of bending and covering canes in winter could be recommended as a method of low temperature stress (LTS) avoidance in raspberry. The manipulation of canes (bending of canes downward in late autumn and bringing them up to vertical in early spring) did not cause visible cane damage. Leaving one cane more per plant for winter protection than necessary would secure enough canes in good condition for the coming season. However, how well this method is adapted to the crop depend on cultivar. The experiments here show 
that 'Glen Ample' gave a much higher fruit yield when the canes were tied in an erect position than bending the canes for winter protection. This effect was not that dominant for 'Stiora' and the selection KV91-39-7. The difference between cultivars was at least partly related to the relatively weak growth of 'Stiora' and KV91-39-7 compared with 'Glen Ample' in a heavy loam clay soil. Several canes within a plot did not reach the pruning height of $160 \mathrm{~cm}$, leaving a high number of poorly developed cane buds at the tip of the canes resulting in weaker flower shoots and fewer fruits than on a normally developed cane bud. On a normal cane of two meters full length, the yield would be reduced by pruning the cane at the first bud above $160-\mathrm{cm}$ height. This height is considered as a standard pruning height in Norway. Fruit yield could be higher by tipping at a higher level saving one or two more cane buds [14]. However, $160 \mathrm{~cm}$ is practical for harvest and in addition the buds have a poorer development, and they often suffer from freezing injury and develop smaller and often crumbly fruits the closer they are situated to the tip of the cane.

Even though we observed only small negative effects of bending and that covering and heating improved the temperature conditions, the methods reduced fruit yield in spite of lowering freezing injury in cane buds (Fig. 5). One hypothesis is that leaving the canes in a horizontal position until anthesis in spring, could have a negative effect on the reproductive (flower bud) development. We observed among the plants in CBH plots in which the canes were lifted directly to an erect position after the winter cover was removed and the buds were still at rest, that flower shoots developed in a repeating spiral. In the case of canes that were left in horizontal position from bud break to anthesis, all flower shoots extended upward, indicating that the flower shoots emerging from the bud oriented sideways and even downward on the bent canes, were capable of bending away from gravity and grow upward. This suggest that the canes should be spaced at least $12 \mathrm{~cm}$ apart on the trellis to allow flower shoots emerging from buds oriented downward to grow upward without restriction from adjacent canes. It is possible that the buds oriented downward from late autumn to early spring produced fewer flower buds and that each flower bud initiated may differentiate fewer pistil primordia than those buds located on upper side of horizontally oriented canes. Higher yields were recorded for all cultivars on erect canes, than for canes left in horizontal position during anthesis, to force flower laterals to grow upward.

During flowering and harvest the distance between laterals of the $\mathrm{BH}$ (treatment $\mathrm{C}$ ) plants was very crowded. It was shown that the fruit weight in $\mathrm{CBH}$ (treatment $\mathrm{E}$, the last experimental year) was larger than in BH, for 'Stiora'. For 'Glen Ample' the fruit weight was nearly equal for the two treatments, but in 'Stiora' the number of fruits on BH plants was larger than the on $\mathrm{CBH}$ plants. This indicates that the $\mathrm{CBH}$ plants of 'Glen Ample' developed more fruits than the BH plants without reduction in fruit weight, while the effect was opposite in 'Stiora'. A suggestion for why 'Stiora' developed smaller fruits when all laterals were bent to one direction than when the laterals were positioned in a whirling spiral, could be the phenotypic pattern with soft laterals laying on the top of each other like tiles. A hypothesis is that the tiling of laterals could lead to reduction in total photosynthesis and reduced pollination since leaves covered each other reducing photosynthesis as described by Larcher [1]. To reduce the lateral density horizontal wires could be stretched along the hedge to support the laterals, giving a potential to improve both photosynthesis and pollination.

Another situation that should be noted was that because of the nature of the experiment (three cultivars and single or groups of plots being bent and lifted), there was more handling of the canes than would be the situation in a growers field, where the entire row would be moved up and down simultaneously. Also, lowering the tile to the ground as we did in these experiments, are probably not necessary, and the tile should be left horizontal during winter, since this would avoid some potential damage of the canes. Generally handling of canes introduce a risk to tear off buds. The recorded reduction in bud numbers, mainly on the section of the cane that were attached to the two wires, was significant between treatments $\mathrm{BH} / \mathrm{CBH}$ and $\mathrm{B}$ (Fig. 6), which suggest that adding heat under the cover strengthen the cane buds. Anyway, it should be adviced to handle the canes carefully.

Another possibility of reduction in yield was that the connection between cane and mother plant could have been affected by bending, reducing transport of water and minerals from the mother plant and into the cane. However, only very few canes were torn off the mother plant. If cane breakage is occurring at the base then the problem can be remedied by leaving one extra cane per plant during pruning in late autumn as a replacement cane.

To demonstrate the potential of the RCA trellis and growing in polytunnel, the blackberries 'Obsidian', 'Natchez' and 'Quachita' were planted in 2011, 2012 and 2012 respectively, in a polytunnel next to the LTS-experiments. They had no winter cover, but 'Obsidian' wintered well in the mild winters 2011/2012 and 2014/2015. The winters in between canes were almost totally killed by freezing. 'Natchez' had poor winter survival similar to 'Obsidian, 
while 'Quachita' had minor freezing injury in the cold winters. There are a strong potential to increase the yield of blackberries, reducing winter injury by introducing the RCA trellis similar as for the raspberries in our experiments. This together with season extention by technical means and choice of cultivar, will give the possibility to add a new crop to horticulture in mid-Norway [7-10].

\section{Conclusions}

The experiments showed that the RCA trellis system can be used to bend the floricanes of raspberries with the tips of $1.6 \mathrm{~m}$ long floricanes reaching the ground without creating much visible cane injury. However, the plants with canes maintained upright in winter generally gave higher fruit yield though there were genotype differences. In the coldest winters freezing injury was reduced when canes was bent and covered with a double Agrocover foil, and there was positive effect of heating on fruit yield of 'Stiora' and KV-91-39-7 but not on 'Glen Ample'. However, the results will depend on genotypes selected, keeping in mind that the canes have to be handled carefully. In areas were the winters are equal to or colder than in the experimental area the method could be recommended. The system would also have a potential in related crops like blackberry.

\section{Acknowledgments}

We will forward thanks to technician Sigrid Alstad for executing research treatments, administrating data collection and the running keeping of the experimental field. These experiments are a part of the EUBerry project funded by the "Seventh Framework programme" of EU, under call FP7-KBBE-2010-4, grant agreement no: 265942, and economical support from Norwegian Institute for Agricultural and Environmental Research, Norway.

\section{References}

[1] Larcher W. Physiological plant ecology. Ecophysiology and stress physiology of functional groups. 4th edition. Springer Verlag; Berlin; Heidelberg; 2003.

[2] Nestby R. Ni plantetidspunkt og to toppehøgder I bringebærkultivaren 'Veten'. Forsk Fors Landbr. 1981;32:35-43 (In Norwegian).

[3] Thorsrud J, Hjeltnes AQ. Undersøkelser over frostherdighet hos bringebær. Forsk Fors Landbr. 1962:99-117. (In Norwegian).

[4] Jennings DL, Charmichael E. Variations in the time of acclimation of raspberry canes in Scotland and Ireland and its significance for hardiness. Hort Res. 1972;12:187-200.

[5] Pacholak E. Factors affecting frost tolerance of raspberry canes. Acta Hort. 1978;81:97-101.

[6] Warmund MR, George MF, Ellersieck MR. Suceptibility of blackberry tissues to freezing injury after exposure to $-16^{\circ} \mathrm{C}$. J Am Soc Hort Sci. 1989;114:795-800.

[7] Takeda F, Peterson DL. Considerations for machine harvesting fresh-market eastern thornless blackberries: Trellis design, cane train systems, and mechanical harvester development. HortTechnology. 1999;9:16-21.

[8] Takeda F, Glenn DM, Tworkoski T. Rotating cross-arm trellis technology for blackberry production. J Berry Research. 2013;3:25-40.

[9] Takeda, F, Rose A. Lateral cane lengths affect yield components in 'Triple Crown' blackberry on rotating cross-arm trellis and cane training system. International Journal of Fruit Science. 2015;15:281-9.

[10] Takeda F, Phillips J. Horizontal cane orientation and rowcover application improve winter survival and yield of trailing 'Siskiyou' blackberry. HortTechnology. 2011;21:170-5.

[11] Stiles HD. Limited arm-rotation shift-trellis (LARS) and primocane management apparatus (PMA) for raspberries and blackberries (Rubus cvs. or crops). Virginia Agr Expt Sta Bul Ser. 1999;99-1.

[12] Nestby R. Screening red raspberry (Rubus idaeus L.) germplasm for freez tolerance in Norway. Acta Agriculturae Scandinavica, Sect B, Soil and Plant Science. 1992;42;189-96.

[13] SAS. SAS priority software 9.2 (TS1M0), W32 VSPRO platform, copyright (c) 2002-2008. SAS Institute INC., Cary, NC, USA.

[14] Nestby R. Nitrogen-gjødsling, topping og tynning av årsskudd i bringebærkultivaren 'Veten. Forskning og forsøk i Landbruket. 1984;32:1723 (In Norwegian). 